\title{
Bioactivity of Kemangi Leaves (Ocimum sanctum) and Ruku Leaves (Ocimum tenuiflorum)
}

\author{
Fri Rahmawati ${ }^{1}$, Hertina Silaban ${ }^{2}$ \\ ${ }^{1,2}$ Faculty of Medicine, Universitas Kristen Indonesia, Jakarta \\ Corresponding Author: Fri Rahmawati
}

\begin{abstract}
Kemangi (Ocimum sanctum) is commonly used as a vegetable (fresh vegetables) and traditional medicine in Indonesia. Kemangi leaves have been empirically used as an alternative medicine for wound healing. Apart from kemangi, a morphologically similar plant to kemangi, namely ruku ruku, is often used by Indonesians as a cooking spice. The leaves of ruku ruku (Ocimum tenuiflorum) have been empirically used in various alternative medicine, namely to treat fever, cough, gout, nerves, mouth sores, tinea versicolor, nausea and vomiting. The research was conducted to determine the antimicrobial activity (antibacterial and antifungal), antioxidants and phytochemical analysis of the ethanol extract of kemangi leaves and ruku ruku leaves. The extraction method used is the maceration method using $96 \%$ ethanol as a solvent. The antimicrobial test was carried out using the agar diffusion method. The bacteria used are Salmonella typhi, Staphylococcus aureus, while the fungi used are Candida albicans. Phytochemical analysis used the Harbone method, and the antioxidant test used the 1,1-Diphenyl-2-picryl Hidrazil (DPPH) method. The results showed that the extracts of kemangi and ruku ruku leaves contained flavonoid and steroid compounds. The antimicrobial test results showed that only ruku ruku leaves inhibited the growth of Staphylococcus aureus with an inhibition zone of $9.35 \mathrm{~mm}$, and the two extracts used could not inhibit the growth of the fungus Candida albicans. In contrast, the results of the antioxidant test showed that the ruku ruku and kemangi leaf extracts had an antioxidant activity with inhibition concentration $50\left(\mathrm{IC}_{50}\right)$ values of $225.64 \mathrm{ppm}$ and $455.11 \mathrm{ppm}$.
\end{abstract}

Keywords: Bioactivity, Kemangi, Phytochemicals, Ruku.

\section{INTRODUCTION}

Indonesia is a country rich in various kinds of plants that can be processed into traditional medicine. In general, traditional medicinal ingredients are made from natural biological sources such as animals and plants. The use of plants as medicinal plants is a legacy that has been passed down from generation to generation. Apart from being medicinal ingredients, many of the plants commonly consumed as food include kemangi and ruku, but the benefits of these two types of plants for clinical health are not yet clearly known.

Kemangi (Ocimum sanctum) is a wild plant found on roadsides and garden edges. Kemangi is a plant that is commonly consumed as a vegetable in the form of fresh vegetables. Apart from being a food ingredient (vegetable), kemangi can also be used as traditional medicine. Kemangi leaves have been used empirically as an alternative medicine for wound healing. It is closely related to the content of active compounds in kemangi. Several studies have shown that kemangi leaves can be antiinflammatory, antimicrobial, antioxidant, and analgesic. The potential of kemangi leaves as raw material for herbal medicine is closely related to the essential oil content contained in kemangi leaves, including methyl chavicol and linalool, which are suspected to be antifungal ${ }^{[1]}$. Other classes of bioactive compounds found in kemangi 
leaves are flavonoids and phenols. Essential oil is the main ingredient in kemangi. The essential oil content in kemangi leaves can inhibit Staphylococcus aureus bacteria and the fungus Candida albicans ${ }^{[1]}$.

The community has widely used ruku (Ocimum tenuiflorum). Ruku leaves can be used to treat fever, cough, gout, nerves, mouth sores, tinea versicolor, nausea and vomiting. Ruku seeds can be used to treat constipation, gonorrhoea, eye diseases, while ruku root is used to treat skin diseases. Ruku plants contain flavonoids, triterpenoids, essential oils, alkaloids, tannins and saponins ${ }^{[2]}$. The ruku ruku plant has properties as antioxidants, antimicrobials, anti-mutagens, and allergy based on its chemical content.

This study aims to determine the biological activity of kemangi and ruku leaves in vitro which includes antimicrobial (antibacterial and antifungal) tests, antioxidants and to determine the active compounds from the extracts of the two plants. The research is expected to provide information on the active compound class and bioactivity of the kemangi and ruku leaves.

\section{LITERATURE REVIEW}

\section{Kemangi Leave (Ocimum sanctum)}

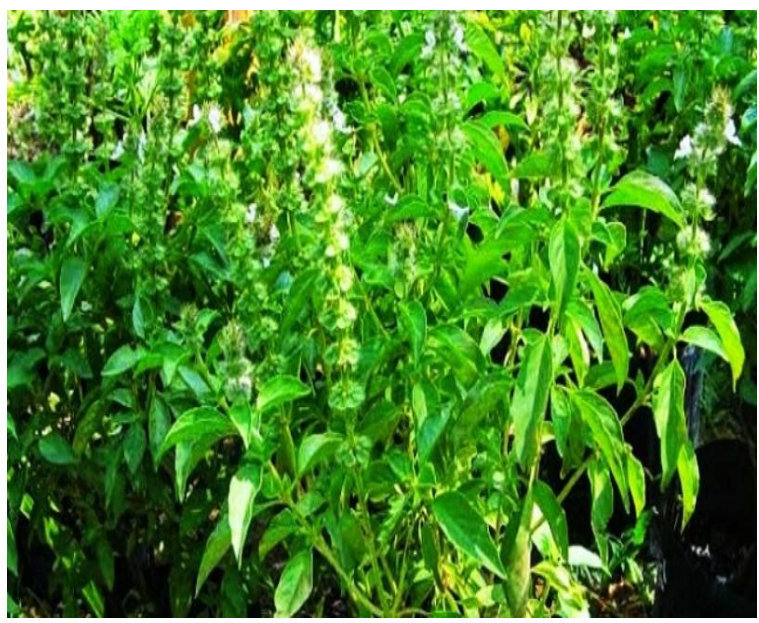

Figure 1. Kemangi Leave (Ocimum sanctum)

(https://lampungkita.id/manfaat-daun-kemangi-bagi-kesehatan/)

Kemangi is a plant that grows a lot in the tropics and is a herb or plant that has wet stems and does not have wood, has a height of 0.3-1.5 m, has many branches, is often purplish green, and is very fragrant, and it can be seen in Figure 1.

Macroscopically, kemangi leaves have oval, elongated, round, round elongated leaves, pointed tip, leaf base pointed or blunt to round, pinnate leaf bones, serrated edges shallow or flat and wavy, thin leaf flesh, fine-haired surface, leaf length $2.5 \mathrm{~cm}$ to $7.5 \mathrm{~cm}$, width $1 \mathrm{~cm}$ to $2.5 \mathrm{~cm}$, round cross-section, smooth hair. Whereas microscopically, it can be seen from the cross-section of the leaf across the leaf bone that the upper epidermis consists of one layer of small cells, rectangular in shape, transparent colour, thin walls, thin and smooth cuticles. Based on several studies that have been carried out on kemangi, it is known that kemangi contains several chemical contents. They are: analgesic, anti amnesia, nootropic properties, anthelmintic, antibacterial, antiinflammatory, anti-fertility, antihyperlipidemic, anti-inflammatory, antimalarial, anti-lipid peroxidative, antioxidant, anti-stress, anti-thyroid, antiinflammatory, anti-ulcer, chemoprotective, skin disease, diabetes, immunomodulatory, radioprotective, hypoglycemic activity, hypotensive activity, and anticancer. Chemical content in kemangi includes tannins, flavonoids, alkaloids, terpenoids, saponins, glycosides, amino acids, namely phenylalanine, lysine, and tryptophan ${ }^{[1]}$.

\section{Ruku Leave (Ocimum tenuiflorum)}

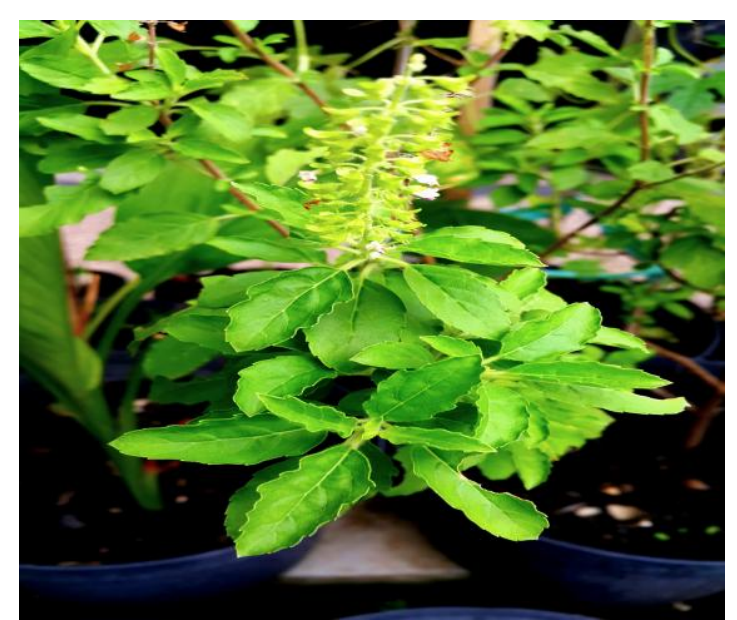

Figure 2. Ruku Leave (Ocimum tenuiflorum) (https://www.kebunpedia.com/media/ruku-ruku.1430/) 
The ruku ruku plant has many branches and has a distinctive aromatic smell, a slightly spicy taste, and green to brownish-green. Leaf-blade elongated, pointed tip, spiky/blunt leaf base, pinnate leaf bone, a shallow serrated edge, thin leaf flesh, and fine-haired leaf surface ${ }^{[3]}$. The morphology of ruku leaves can be seen in Figure 2.

The decoction of ruku-ruku leaves is traditionally believed to treat stomach aches, toothaches, coughs and washing wounds. Ruku leaf extract is used as a phlegm laxative, menstrual laxative, wind release, nausea prevention, appetite enhancer, postpartum medication, seizure reliever, laxative, and externally for rheumatism. At the same time, the seeds are used as a skin softener, urine laxative, sweat and reliever carminative seizures, and antipyretics ${ }^{[2]}$. Chemical content found in ruku-ruku leaves includes essential oils, tannins, flavonoids, steroids/triterpenoids. The phytochemical screening of simplicia powder from rukuruku leaves obtained alkaloids, flavonoids, glycosides, triterpenoids/steroids, tannins, and saponins ${ }^{[3 ; 4]}$.

\section{Phytochemicals}

Phytochemistry is a branch of science that studies various organic compounds stored by plants, namely about the chemical structure, changes, metabolism, and the natural distribution and biological function of organic compounds. Phytochemicals or sometimes called phytonutrients, in a broad sense, are all kinds of chemicals or nutrients derived from plant sources, including vegetables and fruits ${ }^{[3]}$.

Phytochemicals are usually used to refer to compounds found in plants that are not required for normal function but have beneficial effects on health or have a role in preventing and treating various diseases. Phytochemical screening aims to determine which secondary metabolites have biological activity in plants. Secondary metabolites are chemical compounds that are formed in plants. These compounds act as medicines in plants and can benefit humans ${ }^{[3 ; 4]}$.

Phytochemical screening is a way to identify bioactive through a test or rapid examination to separate natural materials that contain certain phytochemicals from natural materials that do not contain certain phytochemicals. Phytochemical screening is a preliminary stage in a study aiming to provide an overview of the class of compounds in plants ${ }^{[5]}$.

Secondary metabolites are compounds resulting from the biosynthesis of primary metabolites. Secondary metabolites are usually produced by higher plants but are not directly determinants of survival but result from the organism's selfdefence mechanisms. Several secondary metabolites have been shown to act as anticancer, antibacterial, and antioxidants, including the alkaloids, tannins, polyphenols and their derivatives. The phytochemical analysis also aims to determine the characteristics of active compounds that cause toxic effects or beneficial effects, shown by the extract when tested with a biological system. Phytochemical analysis is part of the science of pharmacognosy, which studies methods of analyzing chemical content in plants or animals in whole or in part, including how to isolate or separate chemical substances ${ }^{[4 ; 6]}$.

The phytochemical screening method is carried out by looking at the qualitative reaction of colour changes using a reagent. The important thing that plays an essential role in phytochemical screening is the solvent and extraction method. Phytochemical screening carried out on samples in simplicia, and wet samples usually include tests for alkaloids, flavonoids, terpenoids/steroids, tannins and saponins according to the procedures performed by Harbone ${ }^{[3 ; 4]}$.

\section{Antibacterial}

Antibacterials are agents that kill microorganisms by suppressing bacterial multiplication or growth. Antimicrobials are substances or drugs commonly used to 
eradicate microbial infections in humans, including antibiotics, antiseptics, disinfectants, and preservatives. Antimicrobial drugs must be selective toxicity, meaning that the drug or substance must be toxic to disease-causing microorganisms but not toxic to the host or host body ${ }^{[7]}$. Antibacterial properties can be grouped into two, namely bacteriostatic and bacteriocide. Bacteriostatic are substances or materials that can inhibit bacterial growth. Bacteriocides are substances or materials that can kill bacteria directly ${ }^{[8]}$.

Based on an antibacterial mechanism, it can be divided into five groups: inhibiting cell metabolism, inhibiting cell wall synthesis, disrupting cell integrity, inhibiting cell protein synthesis, and inhibiting cell nucleic acid synthesis bacterium. Antibacterial that works by inhibiting microbial cell metabolism is usually bacteriostatic. Some of the antimicrobials that can inhibit the metabolic process of bacterial cells are sulfonamides, trimethoprim, p-aminosalicylic acid and sulfones. Pathogenic bacteria need folic acid, so the bacteria must synthesize folic acid from amino benzoate themselves for survival. If sulfonamides can inhibit the formation of para-aminobenzoic acid (PABA), a non-functional folic acid analogue will be formed so that the microbial balance will be disturbed ${ }^{[9]}$. Antibacterial can inhibit microbial cell wall synthesis. In bacteria, there is a cell wall consisting of polypeptidoglycan. The drugs in this group are penicillin, cephalosporins, bacitracin, vancomycin, and cycloserine. Cycloserine can inhibit the early reaction of cell wall synthesis. Bacitracin, vancomycin, and finally, by penicillin and cephalosporins, because the osmotic pressure in bacteria is higher, the cell wall lysis will occur to become the basis for the bactericidal effect of bacteria ${ }^{[10]}$. Antibacterial can interfere with the integrity of microbial cell membranes included in this group are polymyxin, pollen group, and chemotherapeutic antimicrobial. Polymyxin damages cell membrane after reacting with phosphate on microbial cell membrane phospholipids. Damage to the cell membrane causes the release of various components in it, namely nucleic acids, proteins, nucleotides, and others ${ }^{[6]}$.

Antibacterial can inhibit microbial cell protein synthesis. For the sake of microbial survival, various protein syntheses are required. Included in this group are aminoglycosides, macrolides, tetracyclines, chloramphenicol, linezolid and lincomycin. Aminoglycoside drugs will interfere with the formation of proteins in the ribosomes by binding to the $3 \mathrm{OS}$ or $5 \mathrm{OS}$ ribosomes so that functional $7 \mathrm{OS}$ does not form. Antibacterial can inhibit nucleic acid synthesis. Works by interfering with the formation of folic acid so that bacterial life is disrupted and consequently will be inhibited. This group includes sulfonamides, quinolones, rifampin, trimethoprim, azoles, and sulfones ${ }^{[6]}$.

\section{Antifungal}

Antifungal is a substance that is used specifically for the treatment of fungal diseases. A compound is said to be an antifungal agent if the compound can inhibit or even stop the growth of fungi. Antifungal substances work by causing damage to cell walls, changes in cell permeability, changes in protein and nucleic acid molecules, inhibition of enzyme work, or inhibition of nucleic acid and protein synthesis. Damage to cell walls, changes in cell permeability, changes in protein and nucleic acid molecules, inhibition of enzyme work, or inhibition of nucleic acid and protein synthesis can initiate changes that lead to cell death ${ }^{[11 ; 12]}$.

The antifungals work by destroying the cell walls of fungi. The cell walls are protective for cells and also participate in specific physiological processes. The fungal cell wall structure can be damaged by inhibiting its formation or altering it once it is formed. Antifungal can cause changes in the permeability of fungal cells. The cytoplasmic membrane maintains certain substances in the cell and selectively 
regulates the flow of substances in and out between cells and the external environment. The membrane maintains the integrity of the cellular components. The membrane is also the site of several enzyme reactions. Damage to the membrane results in cell growth inhibition or causes cell death ${ }^{[11 ; 12]}$.

Antifungal works by changing the protein molecules and nucleic acids of fungi; fungal cells depend on the maintenance of protein molecules and nucleic acids in the membrane. A condition or substance that changes the state of protein molecules and fungal nucleic acids, namely denaturing proteins and nucleic acids can damage cells irreversibly. High temperatures and total concentrations of several chemicals can lead to coagulation (denaturation), irreversible (irreversible). Antifungal inhibits the action of certain enzymes in fungi. Various enzymes present in fungal cells are potential targets for the action of an inhibitor. Many chemicals are known to interfere with biochemical reactions. This inhibition can result in disruption of metabolism or cell death. Antifungal inhibits the synthesis of nucleic acids, DNA molecules, RNA and proteins, which play a significant role in everyday life processes of cells. It means that any disturbance in the formation or function of these substances can result in total damage to cells ${ }^{[13 ; 14]}$.

\section{Anti-fungal Activity Testing Methods}

The antifungal compound test is a test to determine whether a compound can inhibit fungi' growth by measuring the response of the growth of the microorganism (fungal) population to the antifungal agent ${ }^{[15]}$.

Some of the antifungal test methods include the diffusion method and the dilution method. The diffusion method can be done in 3 ways: the cylinder, hole, and paper disc method. The cylinder method is to place several cylinders made of glass or stainless steel on top of the media that has been inoculated with the fungus. Each cylinder is placed to stand on the agar medium, filled with the solution to be tested and incubated. The hole method (well) is to make a hole in the solid agar that has been inoculated with the fungus. The number and location of the holes are adjusted to the purpose of the study. The holes are filled with the solution to be tested. The paper disc method is to place the disc paper soaked in the test solution on the solid media that has been inoculated with the fungus ${ }^{[16]}$.

While the dilution method is carried out by diluting the test solution to obtain several concentrations, each concentration of the test solution is added to the fungal suspension in the media. Insubstantial dilution, each concentration of the test solution is mixed into the agar medium and solid, then planted with mushrooms. The dilution method is usually used to determine the minimum inhibitory level and the minimum kill rate of an antimicrobial agent. The principle of the dilution method uses a series of test tubes filled with a liquid medium, and a certain number of microbial cells are tested. Furthermore, each tube was filled with an antifungal agent that had been diluted serially. The tube series was incubated at 37o $\mathrm{C}$ for 18-24 hours and observed the lowest concentration of antimicrobial turbidity in the tubes, which was shown by the culture results that began to appear clear (none fungal growth is the minimum inhibitory concentration). Cultures of all clear tubes were grown on a solid agar medium, incubated for 24 hours and observed for the presence or absence of fungal colonies. The lowest concentration of the antifungal agent in solid medium culture, indicated by the absence of fungal growth, is the minimum killing concentration of the antifungal agent against the tested fungus ${ }^{[17]}$.

\section{Antioxidants}

Antioxidants are compounds that have a way of working to delay, slow down and prevent the process of lipid oxidation. In a specific sense, antioxidants can delay or prevent the occurrence of free radical 
reactions in lipid oxidation. Antioxidants are electron-giving or reductant compounds. These compounds have a small molecular weight but can inactivate the development of oxidation reactions by preventing the formation of radicals ${ }^{[18]}$. Antioxidant compounds function as scavengers for free radicals, form complexes of prooxidant metals, and reduce compounds. Antioxidants can scavenge free radicals, thereby inhibiting oxidative mechanisms that cause degenerative diseases, namely heart disease, cancer, cataracts, brain dysfunction, and arthritis. Based on the source, antioxidants are divided into two groups, namely synthetic antioxidants (antioxidants obtained from the synthesis of chemical reactions) and natural antioxidants (antioxidants extracted from natural materials) ${ }^{[19]}$.

Five types of antioxidants are permitted to be used as food additives, and their use is widespread throughout the world, namely butyl hydroxy anisol (BHA), butylhydroxytoluene (BHT), propyl gallate, tert-butyl hydroxy quinone (TBHQ), and tocopherol (vitamin E). ) ${ }^{[20]}$. Natural antioxidants found in food come from: (a) existing antioxidant compounds from one or two food components, (b) antioxidant compounds formed from reactions during processing, and (c) antioxidant compounds isolated from sources natural and added to food as a food additive. The compounds that are generally contained in natural antioxidants are phenols, polyphenols, and the most common are flavonoids (flavonols, isoflavones, flavones, catechins, flavonoids) cinnamic acid derivatives, tocopherols, and polyfunctional organic acids. Now tocopherols have been produced synthetically for commercial purposes. Sources of nutrients that contain antioxidants include all whole grains, fruits, vegetables, liver, oysters, poultry, shellfish, fish, milk, and meat. Natural vitamin E can be found in wheat germ (wheat), vegetable oils, green leafy vegetables, egg yolks, and nuts. Natural vitamin $\mathrm{C}$ can be found in citrus fruits, tomatoes, melons, cabbage, guava, and strawberries. Beta carotene (provitamin A), an important antioxidant of carotenoids, can be found in apricots, carrots, beets, cassava leaves, spinach leaves, and red sweet potatoes ${ }^{[21]}$.

The mechanism of action of antioxidants is grouped into two, namely primary antioxidants and secondary antioxidants. A compound can be said to be a primary antioxidant if the compound can provide hydrogen atoms quickly to lipid radicals $\left(\mathrm{R}^{*}, \mathrm{ROO}^{*}\right)$ or change it to a more stable form, while the derivative of antioxidant radicals $\left(\mathrm{A}^{*}\right)$ has a more stable state than lipid radicals. The work of the secondary antioxidant system is by slowing down the autoxidation rate by various mechanisms outside the mechanism of breaking the autoxidation chain by converting lipid radicals to a more stable form. A suitable antioxidant will react with fatty acid radicals as soon as these compounds are formed. The mechanism of antioxidants in inhibiting oxidation or stopping the chain reaction of free radicals from oxidized fats can be caused by four kinds of reaction mechanisms, namely: (1) the release of hydrogen from antioxidants; (2) the release of electrons from antioxidants; (3) addition of fat to the aromatic ring in antioxidants; and (4) the formation of a complex compound between the fat and the aromatic ring of the antioxidant $^{[22]}$.

The method to see antioxidants using DPPH (2,2-diphenyl-1picrylhydrazyl) as free radicals are most often used to screen the antioxidant activity of various medicinal plants. The method is based on reducing a methanol solution in coloured DPPH free radicals with free radical inhibition. This method involves measuring the reduction in DPPH uptake at its maximum wavelength, proportional to the concentration of free radical inhibitors added to the DPPH reagent solution ${ }^{[23]}$.

$\mathrm{IC}_{50}$ (inhibition concentration 50) is a value that shows the ability to inhibit the oxidation process by $50 \%$ a sample concentration $(\mathrm{ppm})$. The smaller $\mathrm{IC}_{50}$ value 
indicates the higher the antioxidant activity. A compound is said to have potent antioxidant activity if the $\mathrm{IC}_{50}$ value is less than $50 \mathrm{ppm}$, the potent antioxidant for $\mathrm{IC}_{50}$ is $50-100 \mathrm{ppm}$, moderate antioxidant if the $\mathrm{IC}_{50}$ value is $100-150 \mathrm{ppm}$, and weak antioxidants if the $\mathrm{IC}_{50}$ value is 151200ppm.

\section{RESEARCH METHOD}

The research design used was a laboratory experimental research method to determine the active compound (phytochemical analysis) and bioactivity (antibacterial, antifungal, and antioxidant) groups of kemangi (Ocimum sanctum) and ruku ruku (Ocimum tenuiflorum) leaves. The research was conducted at the Microbiology Laboratory, Parasitology Laboratory, Faculty of Medicine, Christian University of Indonesia and the Biopharmaca Laboratory of IPB Bogor. The study was conducted from September to December 2019. Kemangi leaves (Ocimum sanctum) and ruku ruku (Ocimum tenuiflorum) were taken from the Kramat Jati wholesale and Padang herbal grocery stores, which were extracted using 96\% ethanol at the Microbiology Laboratory of Faculty of Medicine, Christian University of Indonesia. The formula used to determine the sample size is Federer's formula.

$$
\begin{gathered}
(\mathrm{n}-1)(\mathrm{k}-1) \geq 15 \\
(\mathrm{n}-1)(6-1) \geq 15 \\
(\mathrm{n}-1) 5 \geq 15 \\
5 \mathrm{n}-5 \geq 15 \\
\mathrm{n} \geq 4
\end{gathered}
$$

Information:

$\mathrm{n}=$ number of samples (repetitions)

$\mathrm{k}=$ number of treatments

Based on the results above, the sample size used is 4 . The tools used in the study were test tubes, test tube racks, Petri dishes, filter paper, tweezers, Bunsen, Erlenmeyer tubes, measuring pipettes, micropipettes, incubators, ose, scales and evaporators. The research materials used in the study included kemangi leaves, ruku ruku, test bacteria (Staphylococcus aureus and Salmonella typhi), Candida albicans fungi, Mueller Hinton Agar (MHA) media, Saboroud Dextrose Agar (SDA) media, Mannitol Salt Agar media. (MSA), Salmonella Shigella agar (SSA) medium, 1,1-diphenyl-2-picrillhydrazil (DPPH) reagent, $96 \%$ ethanol, sterile distilled water, $\mathrm{NH}_{3}, \quad \mathrm{CHCl}_{3}, \mathrm{H}_{2} \mathrm{SO}_{4}, \quad$ Mayer reagent, Wagner reagent, Dragendorf reagent. The stages of testing carried out are as follows: a) Phytochemistry (Harbone Method) ${ }^{[3]}$; b) Antibacterial Test (Kirby Bauer Method) ${ }^{[6 ;}$ ${ }^{10]}$; c) Antifungal Test (Diffusion Method) [4]; and d) Antioxidant Test (DPPH Method) ${ }^{[8 ; 9]}$. The data was obtained descriptively by recording the inhibition zone results of Gram-positive Staphylococcus aureus bacteria and Salmonella typhi harmful bacteria after being treated with the extract of kemangi and ruku leaves, negative control (sterile distilled water), and also positive control (chloramphenicol). Recording inhibition zone results in Candida albicans fungi after being treated with kemangi and ruku leaf extracts, negative control (sterile distilled water) with the positive control (fluconazole). Antioxidant comparison data were obtained using the DPPH method to assess $\mathrm{IC}_{50}$. Data presented descriptively in tabular form.

\section{RESULT AND DISCUSSION}

Table 1. Phytochemical Test Results of Kemangi and Ruku Leaves Extracts

\begin{tabular}{|l|l|l|}
\hline \multirow{2}{*}{ Treatment } & Result \\
\cline { 2 - 3 } & Kemangi & Ruku \\
\hline Alkaloids & & \\
\hline Wagner & - & - \\
\hline Mayer & - & - \\
\hline Deggendorf & - & - \\
\hline Flavonoids & + & + \\
\hline Tannins & - & - \\
\hline Saponins & - & - \\
\hline Steroids & + & + \\
\hline Triterpenoids & - & - \\
\hline
\end{tabular}

Note: (-) was not detected to contain the secondary metabolite compound tested, and (+) was detected to contain a small number of secondary metabolite compounds being tested

Phytochemical Analysis of Kemangi Leaves and Ruku Leaves Extracts - The phytochemical analysis included tests of alkaloids, flavonoids, tannins, saponins, steroids and triterpenoids and quinones. The results of the phytochemical test of the 
extract of kemangi leaves and ruku ruku leaves can be seen in Table 1 .

Based on Table 1, it is known that the extracts of kemangi leaves and ruku leaves contain active compounds of the flavonoid and steroid groups that may occur due to processing errors such as maceration, improper simplicia. In a study with the same method, Kemangi leaves and ruku contained active alkaloid compounds, saponins, flavonoids, tannins, and steroids ${ }^{[24 ; 25]}$. In research with the thin layer chromatography method of kemangi leaves and ruku, there are active alkaloids, saponins and tannins.

Flavonoids have antioxidant, antibacterial, antifungal and antiviral activity. Steroids have antibacterial and antifungal activity. Antibacterial activity can be caused by the presence of chemical compounds, namely tannins and flavonoids. Tannins and flavonoids are a group of phenolic compounds. The phenol group has antimicrobial activity, which is bactericidal but not sporicid ${ }^{[26]}$. Phenolic compounds work by denaturing cell proteins and damaging the cell walls of bacteria so that bacteria die. They can also actively promote protein and damage lipids in cell membranes by reducing the surface tension of the cell membranes.
Flavonoids function as antibacterial by damaging the cytoplasmic membrane of bacteria. The bacterial cytoplasmic membrane functions to regulate the entry of food or nutrients, if the cytoplasmic membrane is damaged, the essential metabolites in the bacteria will come out, and food materials to produce energy cannot enter, resulting in the inability of bacterial cells to grow and eventually cell death occurs. Tannins can shrink and damage the cell walls of bacteria, thereby disrupting the permeability of the cells themselves; as a result, the cells cannot carry out life activities, and their growth is inhibited or even causes cell death. Tannin astringent compounds can induce a complex bond to a protein, enzyme or microbial substrate and the formation of a tannin complex bond to metal ions, increasing the toxicity of the tannin itself ${ }^{[27]}$.

Antibacterial Activity Test of Kemangi Leaf Extract and Ruku Ruku - The antibacterial activity test used the agar diffusion method using disc paper (Kirby Bauer Method). The choice of this method was based because it was easy, inexpensive, and did not require special equipment. The results of the antibacterial test of kemangi and ruku leaf extracts against the tested bacteria can be seen in Figure 2.

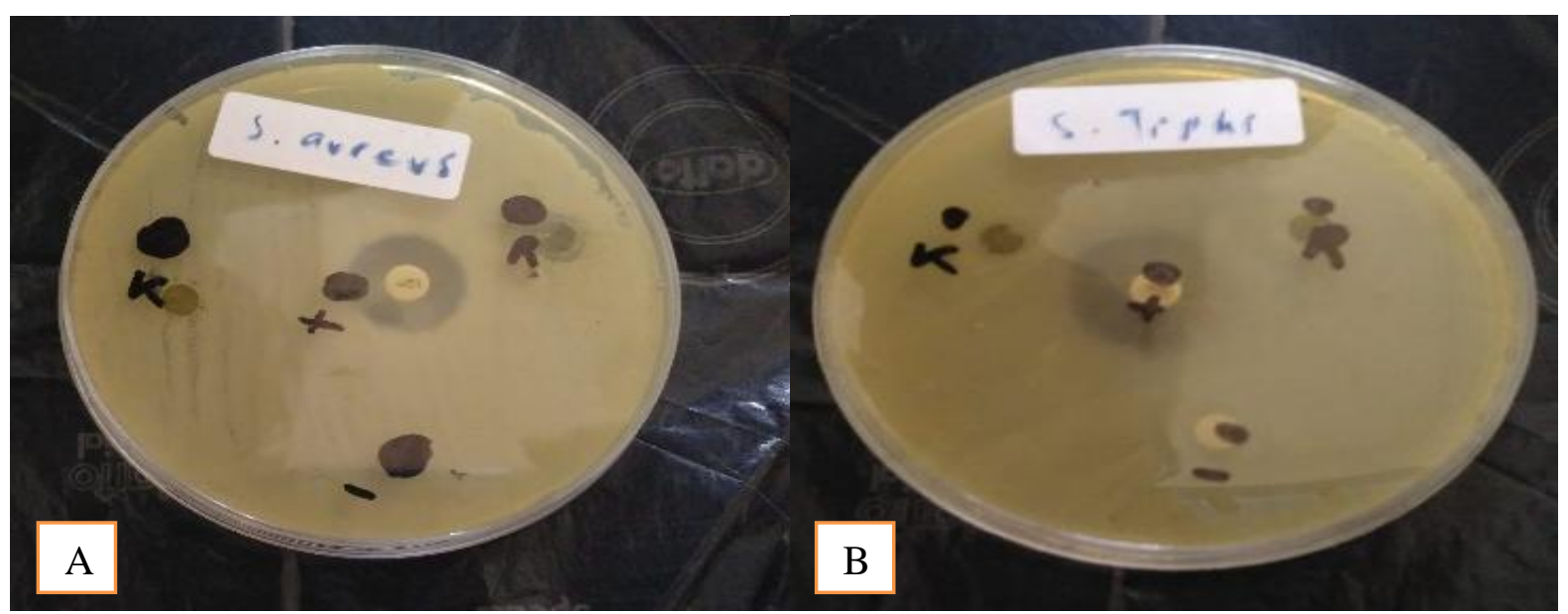

Figure 2. The results of the antibacterial test of kemangi leaf extract (K) and ruku leaf (R) contained bacteria (A) Staphylococcus aureus and (B) Salmonella typhi

Based on Figure 2, it can be seen that only ruku ruku leaf extract and positive control (chloramphenicol) produce a clear zone (inhibition zone) around the disc paper. The diameter of the inhibition zone of the ruku ruku leaf extract and chloramphenicol can be seen in Figure 3. 


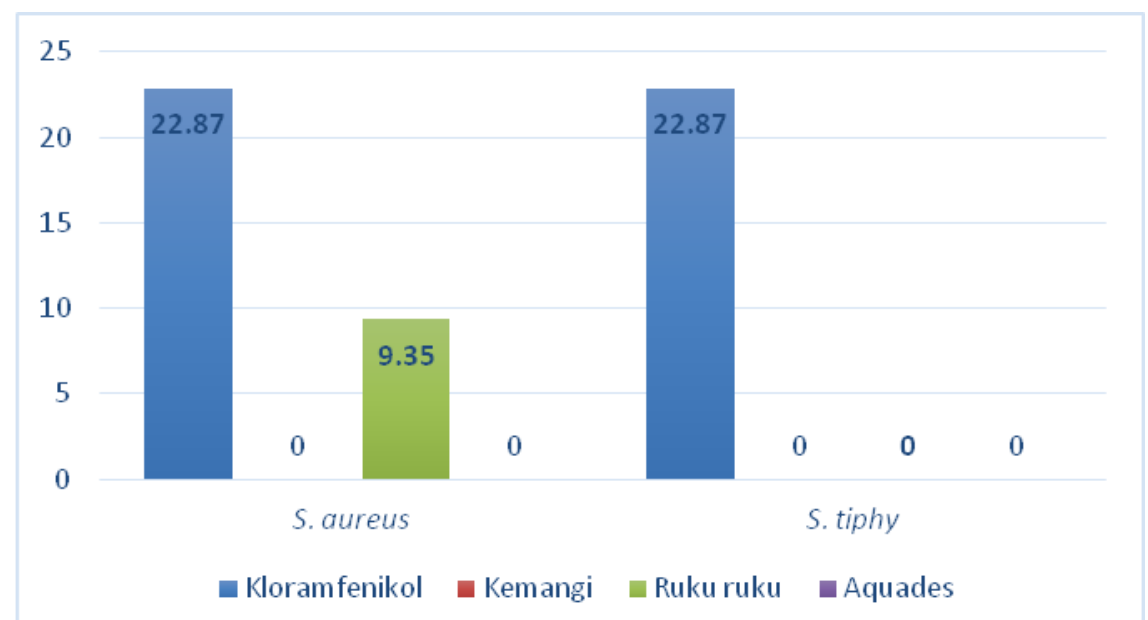

Figure 3. Diameter of sample inhibition zone, chloramphenicol, distilled water, Staphylococcus aureus and Salmonella typhi bacteria.

Based on the graph in Figure 3, it is known that the ruku ruku leaves have an inhibition zone diameter of $9.35 \mathrm{~mm}$. Based on the classification of inhibition according to David Stout (Table 2), the ruku ruku leaf extract is classified as an antibacterial compound that has moderate inhibition because it has a diameter in the range of 5$10 \mathrm{~mm}$. Meanwhile, chloramphenicol showed potent inhibition in $S$. aureus and $S$. Typhi because it has an inhibition zone diameter of more than $20 \mathrm{~mm}$.

Table 2. Inhibition Category According to David Stout [28]

\begin{tabular}{|l|l|}
\hline Bacterial inhibition & Growth Inhibition Response \\
\hline$\geq 20 \mathrm{~mm}$ & Very strong \\
\hline $10-20 \mathrm{~mm}$ & Strong \\
\hline $5-10 \mathrm{~mm}$ & Moderate \\
\hline$\leq 5 \mathrm{~mm}$ & Weak \\
\hline
\end{tabular}

The results of the inhibition of ruku ruku leaf extract, which has a moderate inhibition zone and kemangi leaf extract that does not have an inhibition zone may occur due to errors such as the soil where the plants are grown, when the plants are harvested, processing methods such as maceration, improper simplicia. In the study, it was known that the concentration of ethanol extract of kemangi leaves had the highest inhibition zone in Staphylococcus aureus, namely the concentration of $100 \%$ without dilution with a result of $21.75 \mathrm{~mm}$. The concentration of ethanol extract of kemangi leaves, which has the highest inhibition zone, is at $80 \%$ Salmonella typhi with a yield of $6.25 \mathrm{~mm}{ }^{[6]}$. In this study, the ethanol extract of ruku ruku leaves with the same method had the highest inhibition zone for Staphylococcus aureus at a concentration of $50 \%$, and an inhibition zone of $21.6 \mathrm{~mm}$ was obtained ${ }^{[26]}$. The inhibition of ruku ruku extracts against Salmonella typhi using ethyl acetate extract and $90 \%$ ethanol extract resulted in an inhibition zone of $6.20 \mathrm{~mm}$ and $5.40 \mathrm{~mm}$, respectively ${ }^{[29]}$.

Antifungal Activity Test of Kemangi Leaf Extract and Ruku Ruku Leaf - The antifungal test was performed using $C$. Albicans as the test fungus and fluconazole as the standard antibiotic. The sample's antifungal activity and standard antibiotics are indicated by forming a clear zone around the disc paper. The results of the antifungal test of kemangi and ruku leaf extracts can be seen in Figure 4.

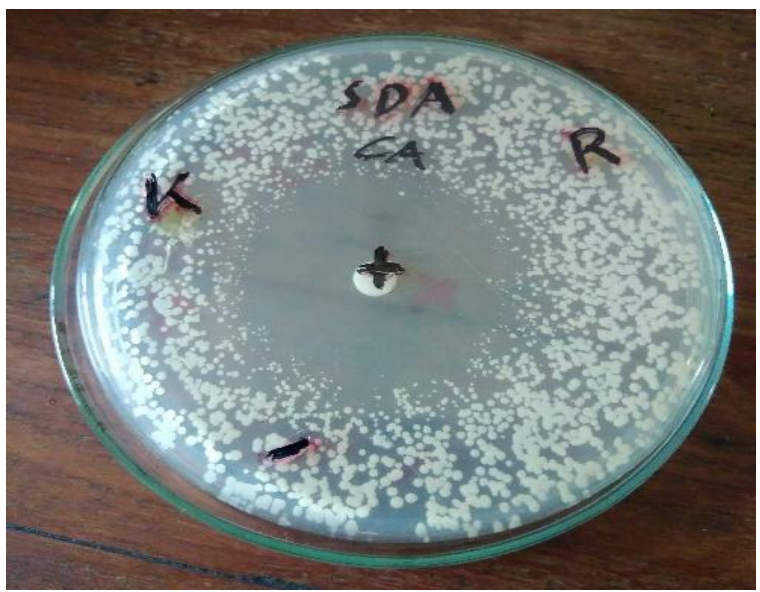

Figure 4. Antifungal activity test results of kemangi leaf extract (K) and ruku ruku leaves (R), positive control (+), negative control (-). 
Based on Figure 4, it is known that the clear zone around the disc paper is only found in fluconazole, while the disc paper containing extracts of kemangi leaves and ruku ruku leaves does not produce clear zones. It means that the two sample extracts used did not provide inhibition against the growth of Candida albicans but differed from standard antibiotics, which produced a clear zone around the disc paper.

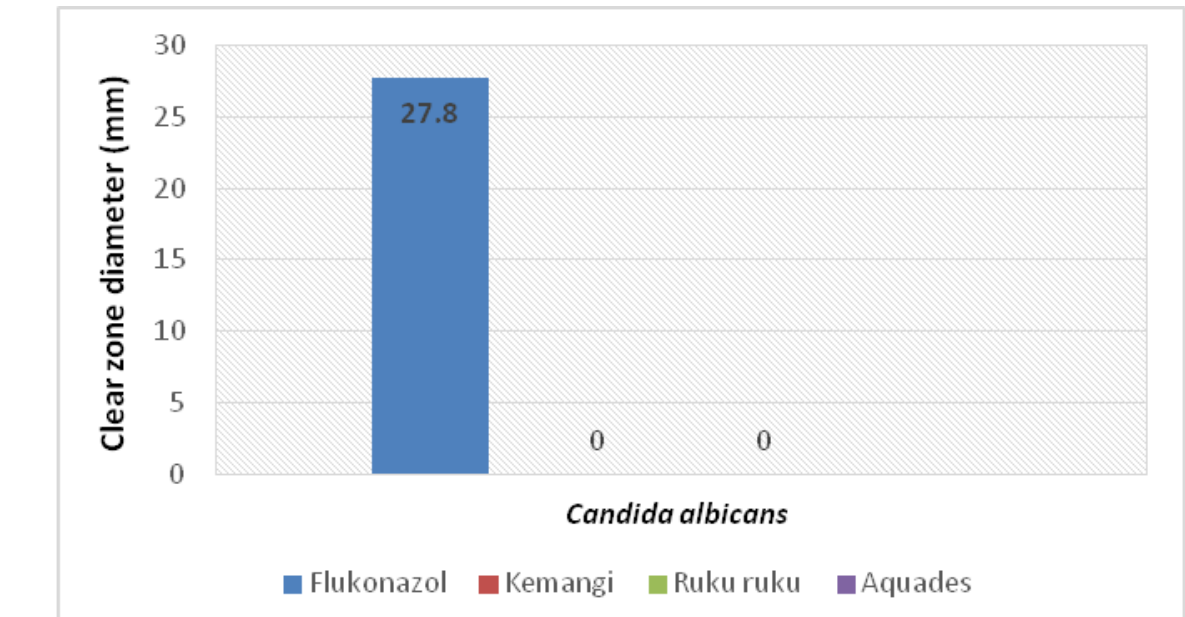

Figure 5. Graph of the antifungal inhibition zone of kemangi and ruku leaves against Candida albicans

Based on the graph in Figure IV.5, it can be seen that there is no clear zone around the disc paper containing extracts of kemangi leaves, ruku ruku, and negative controls, but the clear zone is produced in the positive control (fluconazole) with an inhibition zone diameter of $27.8 \mathrm{~mm}$. shows relatively strong inhibition power. Based on these results, it was known that the two extracts used could not inhibit the fungus Candida albicans. Kemangi leaf extract using the same solvent obtained the highest inhibition zone at a concentration of $100 \%$ with a diameter of $11.9 \mathrm{~mm}{ }^{[30]}$. Ruku leaf extract with $70 \%$ ethanol solvent and $100 \%$ concentration can inhibit the growth of the fungus C. Albicans ${ }^{[31]}$.

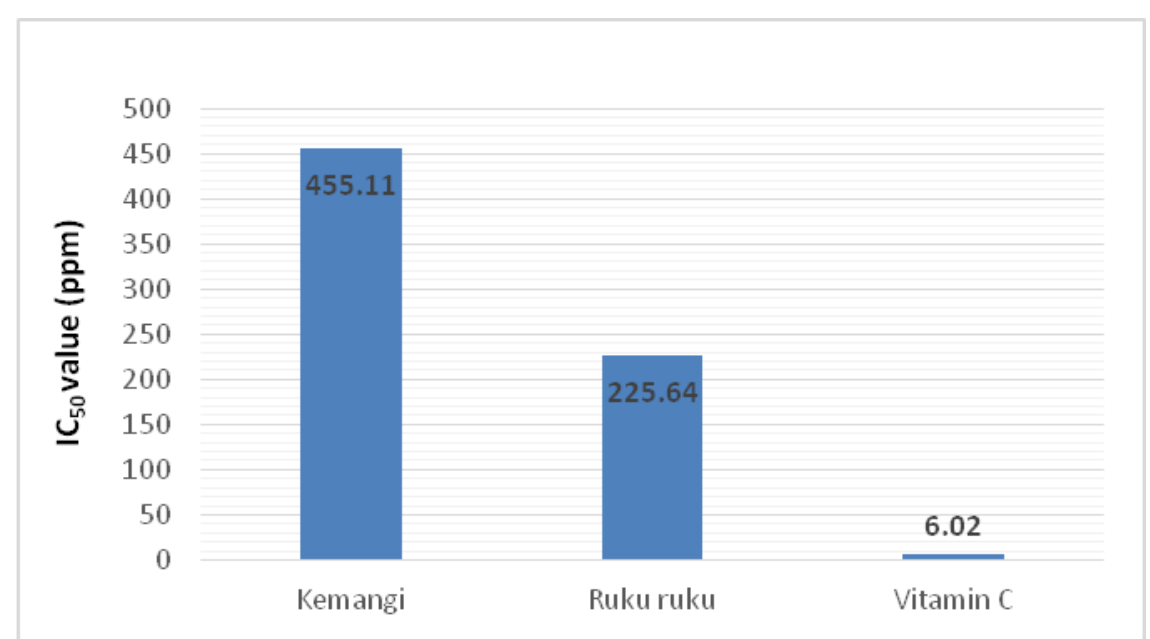

Figure 6. Graph of antioxidant activity of kemangi leaf extract, ruku ruku leaf extract, and vitamin C

Antioxidant Activity Test of Kemangi Leaf Extract and Ruku Ruku - The antioxidant test was carried out using the DPPH method, the choice of this method was because the DPPH method was simple, easy, fast, sensitive, and required a small number of samples. The DPPH method is easy to apply because the DPPH radical compound used is relatively stable compared to other methods ${ }^{[28]}$. Antioxidant 
activity is expressed by the value of inhibition concentration $50\left(\mathrm{IC}_{50}\right) . \mathrm{IC}_{50}$ can be defined as the substrate concentration that can cause a $50 \%$ reduction in DPPH activity ${ }^{[8]}$. The $\mathrm{IC}_{50}$ value in the extract of kemangi leaves and ruku leaves can be seen in Figure 6.

Based on the graph in Figure IV.6, it is known that the two extracts used in the study have antioxidant activity with $\mathrm{IC}_{50}$ values of $225.64 \mathrm{ppm}$ and $455.11 \mathrm{ppm}$, respectively. Based on the $\mathrm{IC}_{50}$ value obtained, it can be seen that the ruku ruku leaf extract has more excellent antioxidant activity than the Kemangi leaf extract, indicated by a low $\mathrm{IC}_{50}$ value. A low $\mathrm{IC}_{50}$ value indicates high antioxidant activity. The antioxidant activity produced by the extracts of kemangi leaves and ruku ruku leaves is weak because the $\mathrm{IC}_{50}$ value is more significant than $200 \mathrm{ppm}$. Kemangi leaf extract has a moderate $\mathrm{IC}_{50}$ value of $52.68 \mathrm{ppm}^{[32]}$. Ruku leaf extract using the $\mathrm{DPPH}$ method is known to have an $\mathrm{IC}_{50}$ value of $46 \mathrm{ppm}^{[33]}$. The smaller $\mathrm{IC}_{50}$ value indicates the higher the antioxidant activity. A compound is said to have potent antioxidant activity if the $\mathrm{IC}_{50}$ value is less than $50 \mathrm{ppm}$, the potent antioxidant for $\mathrm{IC}_{50}$ is $50-100 \mathrm{ppm}$, moderate antioxidant if the $\mathrm{IC}_{50}$ value is $100-150 \mathrm{ppm}$, and weak antioxidants if the $\mathrm{IC}_{50}$ value is 151-200 ppm.

\section{CONCLUSION}

The research results show that the kemangi leaf extract and ruku leaf extract contain active compounds of the flavonoid and steroid classes. Kemangi leaf extracts and ruku ruku leaves could not inhibit the growth of Salmonella typhi bacteria, but ruku ruku leaf extract could inhibit Staphylococcus aureus bacteria with an inhibition zone of $9.35 \mathrm{~mm}$. Kemangi leaf extracts and ruku ruku leaves did not inhibit the growth of the fungus Candida albicans. However, kemangi leaf extract and ruku ruku have antioxidant activity. Ruku ruku leaves have more excellent antioxidant activity than kemangi leaves extract, with an $\mathrm{IC}_{50}$ value of $225.64 \mathrm{ppm}$.

\section{Acknowledgement: None}

\section{Conflict of Interest: None}

\section{Source of Funding: None}

\section{Ethical Approval: Approved}

\section{REFERENCES}

1. Sentari, M., Harahap, U., Sapiie, T. W. A., \& Ritarwan, K. (2019). Blood cortisol level and blood serotonin level in depression mice with basil leaf essential oil treatment. Open access Macedonian journal of medical sciences, 7(16), 2652.

2. Riady, M. H., Rostini, I., Andriani, Y., \& Pratama, R. I. (2019). Effectiveness of the Ruku-ruku Leaf Solution (Ocimum sanctum) as a Natural Preservative in Indian Mackerel (Rastrelliger sp.) during Lowtemperature Storage. Asian Food Science Journal, 1-13.

3. Parbuntari, H., Etika, S. B., Mulia, M., \& Delvia, E. (2019). A Preliminary Screening of the Different of Secondary Metabolites Ruku-Ruku Leaves (Ocimum tenuiflorum Linnen) in West Sumatera. Eksakta: Berkala Ilmiah Bidang MIPA (E-ISSN: 25497464), 20(2), 17-24.

4. Pandiyan, A. (2012). Chemical Profiling and Biological Activity on Leaves of Ocimum Gratissimum Grown in Tamilnadu (Doctoral dissertation, Adhiparasakthi College of Pharmacy, Melmaruvathur).

5. Gavamukulya, Y., Abou-Elella, F., Wamunyokoli, F., \& AEl-Shemy, H. (2014). Phytochemical screening, antioxidant activity and in vitro anticancer potential of ethanolic and water leaves extracts of Annona muricata (Graviola). Asian Pacific journal of tropical medicine, 7, S355-S363.I

6. Khan, A. M., Qureshi, R. A., Ullah, F., Gilani, S. A., Nosheen, A., Sahreen, S., ... \& Murad, W. (2011). Phytochemical analysis of selected medicinal plants of Margalla Hills and surroundings. Journal of medicinal plants research, 5(25), 6055-6060.

7. Wright, P. M., Seiple, I. B., \& Myers, A. G. (2014). The evolving role of chemical 
synthesis in antibacterial drug discovery. Angewandte Chemie International Edition, 53(34), 8840-8869.

8. Birbir, Y., \& Birbir, M. (2006). Inactivation of extremely halophilic hide-damaging bacteria via low-level direct electric current. Journal of electrostatics, 64(12), 791-795.

9. Guzzo, M. B. (2017). Molecular Mechanisms Underlying the Intrinsic Sulfonamide Resistance in Bacteria. Case Western Reserve University.

10. Kohanski, M. A., Dwyer, D. J., \& Collins, J. J. (2010). How antibiotics kill bacteria: from targets to networks. Nature Reviews Microbiology, 8(6), 423-435.

11. Clemens, M. J., Bushell, M., Jeffrey, I. W., Pain, V. M., \& Morley, S. J. (2000). Translation initiation factor modifications and the regulation of protein synthesis in apoptotic cells. Cell Death \& Differentiation, 7(7), 603-615.

12. Lü, J. M., Lin, P. H., Yao, Q., \& Chen, C. (2010). Chemical and molecular mechanisms of antioxidants: experimental approaches and model systems. Journal of cellular and molecular medicine, 14(4), 840860.

13. Durant, S., \& Karran, P. (2003). Vanillins- a novel family of DNA-PK inhibitors. Nucleic acids research, 31(19), 5501-5512.

14. Wang, Y., Feng, K., Yang, H., Zhang, Z., Yuan, Y., \& Yue, T. (2018). Effect of cinnamaldehyde and citral combination on transcriptional profile, growth, oxidative damage and patulin biosynthesis of Penicillium expansum. Frontiers in microbiology, 9, 597.

15. Woodhams, D. C., LaBumbard, B. C., Barnhart, K. L., Becker, M. H., Bletz, M. C., Escobar, L. A., ... \& Minbiole, K. P. (2018). Prodigiosin, violacein, and volatile organic compounds produced by widespread cutaneous bacteria of amphibians can inhibit two Batrachochytrium fungal pathogens. Microbial ecology, 75(4), 10491062.

16. Li, B., Li, Q., Xu, Z., Zhang, N., Shen, Q., \& Zhang, R. (2014). Responses of beneficial Bacillus amyloliquefaciens SQR9 to different soilborne fungal pathogens through the alteration of antifungal compounds production. Frontiers in microbiology, 5, 636 .
17. Stupar, M., Grbić, M. L., Džamić, A., Unković, N., Ristić, M., Jelikić, A., \& Vukojević, J. (2014). Antifungal activity of selected essential oils and biocide benzalkonium chloride against the fungi isolated from cultural heritage objects. South African Journal of Botany, 93, 118-124.

18. Li, Y., Jiang, B., Zhang, T., Mu, W., \& Liu, J. (2008). Antioxidant and free radicalscavenging activities of chickpea protein hydrolysate (CPH). Food chemistry, 106(2), 444-450.

19. Caleja, C., Barros, L., Antonio, A. L., Oliveira, M. B. P., \& Ferreira, I. C. (2017). A comparative study between natural and synthetic antioxidants: Evaluation of their performance after incorporation into biscuits. Food chemistry, 216, 342-346.

20. Tormin, T. F., Almeida, E. S., de Sousa, R. M. F., \& Mathias, E. (2015). Determination of Butylhydroxytoluene, Butylhydroxyanisole, and tertButylhydroquinone. Flow Injection Analysis of Food Additives, 1, 225.

21. Bechoff, A. (2010). Investigating carotenoid loss after drying and storage of orangefleshed sweet potato (Doctoral dissertation, University of Greenwich).

22. Brewer, M. S. (2011). Natural antioxidants: sources, compounds, mechanisms of action, and potential applications. Comprehensive reviews in food science and food safety, 10(4), 221-247.

23. Kedare, S. B., \& Singh, R. P. (2011). Genesis and development of DPPH method of antioxidant assay. Journal of food science and technology, 48(4), 412-422.

24. Utami, P. S. M., Noorhamdani, N., \& Rahayu, M. (2020). The extract of kemangi leaves as inhibitor of biofilm from Staphylococcus aureus in vitro. Journal AMS, 6(3), 168-173.

25. Parbuntari, H., Etika, S. B., \& Delvia, E. (2021, February). Molecular encapsulation of bioactive molecules of Ruku-Ruku leaves (Ocimum tenuiflorum Linnen) as a preliminary stability study. In Journal of Physics: Conference Series (Vol. 1788, No. 1, p. 012002). IOP Publishing.

26. Sher, A. (2009). Antimicrobial activity of natural products from medicinal plants.

27. Chung, K. T., Wong, T. Y., Wei, C. I., Huang, Y. W., \& Lin, Y. (1998). Tannins and human health: a review. Critical 
reviews in food science and nutrition, 38(6), 421-464.

28. Lu'lu' A'lana, Rafika S, Pratiwi A. Determination of FICI Value Combination of Ethanol Extract of Aloe Vera Leaves (Aloe vera (L.) and Gentamicin Sulphate Against Escherichia coli Bacteria. Faculty of Medicine, Tanjungpura University, Pontianak. 2018.

29. Octaviani, P. (2020, February). Identification of Chemical Content and Antihypertensive Activity Test of Ethanol Extract from Tali Bamboo Shoot (Gigantochloa apus (Schult. \& Schult. F.)). In 1st International Conference on Community Health (ICCH 2019) (pp. 237241). Atlantis Press.

30. Himawan, H. C., Isa, A. F., \& Wiharja, D. S. (2021, February). Antioxidant Activity Of $70 \%$ Ethanol Extract Combination of Kemangi Leaf (Ocimum Americanum Linn) and Binahong Leaf (Anredera cordifolia (Ten.) Steenis) Using DPPH. In Journal of Physics: Conference Series (Vol. 1764, No. 1, p. 012009). IOP Publishing.

31. Pandiyan, A. (2012). Chemical Profiling and Biological Activity on Leaves of
Ocimum Gratissimum Grown in Tamilnadu (Doctoral dissertation, Adhiparasakthi College of Pharmacy, Melmaruvathur).

32. Erviana, L., Malik, A., \& Najib, A. (2016). The free antiradical activity test of the ethanol extract of basil (Ocimum basilicum L.) using the dpph method. Jurnal Fitofarmaka Indonesia, 3(2), 164-168.

33. Parbuntari, H., Etika, S. B., \& Mulia, M. (2020, August). Identification and Prediction of Potential Drug-like Compounds from Ruku-Ruku Leaves (Ocimum tenuiflorum Linnen) in West Sumatera. In International Conference on Biology, Sciences and Education (ICoBioSE 2019) (pp. 248-252). Atlantis Press.

How to cite this article: Rahmawati F, Silaban $\mathrm{H}$. Bioactivity of kemangi leaves (ocimum sanctum) and ruku leaves (ocimum tenuiflorum). Int J Health Sci Res. 2021; 11(5): 379-391. DOI: https://doi.org/10.52403/ijhsr. 20210558 